\title{
COMMUNICATING A CONTROVERSIAL AND COMPLEX PROJECT TO THE PUBLIC: YUCCA MOUNTAIN TOURS - REAL AND VIRTUAL COMMUNICATION
}

\author{
by
}

MOL. 20000424.0178

\author{
Allen B. Benson, U.S. Department of Energy \\ Patricia Van Nelson, Booz-Allen \& Hamilton Inc. \\ Melinda d'Ouville, Science Applications International Corp.
}

\section{THE PROJECT}

Since 1983, under the Nuclear Waste Policy Act of 1982, as amended (42 U.S.C. 10101 et seq.), the U.S. Department of Energy (the Department) has been investigating a site at Yucca Mountain, Nevada, to determine whether it is suitable for development as the nation's first repository for permanent geologic disposal of spent nuclear fuel and high-level radioactive waste.

By far, the largest quantity of waste destined for geologic disposal is spent nuclear fuel from 118 commercial nuclear power reactors at 72 power plant sites and 1 commercial storage site across the United States. Currently, 104 of these reactors are still in operation and generate about 20 percent of the country's electricity. Under standard contracts that DOE executed with the utilities, DOE is to accept spent nuclear fuel from the utilities for disposal. Until that happens, the utilities must safely store their spent nuclear fuel in compliance with Nuclear Regulatory Commission regulations. As of December 1998, commercial spent nuclear fuel containing approximately 38,500 metric tons of heavy metal (MTHM) was stored in 33 states.

The balance of the waste destined for geologic disposal in a repository is Department-owned spent nuclear fuel and high-level radioactive waste. The Department's spent nuclear fuel includes naval spent nuclear fuel and irradiated fuel from weapons production, domestic research reactors, and foreign research reactors. For disposal in a geologic repository, high-level radioactive waste would be processed into a solid glass form and placed into approximately 20,000 canisters. No liquid or hazardous wastes regulated under the Resource Conservation and Recovery Act of 1976 would be disposed of in a geologic repository.

The difficulty in siting new facilities, particularly those designed as nuclear or nuclear-related facilities, is well documented. In this context, national boundaries are not significant distinguishing barriers. As one publication observed, "Environmental activists, local residents and governmental officials are protesting proposed waste facilities from Taiwan to Texas."' Here in Nevada, Yucca Mountain is no exception. The Department's study of the Yucca Mountain site for possible development as a permanent repository for spent nuclear fuel and high-level radioactive waste has been criticized by many, for many reasons. The Yucca Mountain Project is both controversial and complex-a fact that makes communication with the public a challenge.

'Nuclear Waste News, Vol. 18, No. 42, October 15, 1998, p. 429 (Business Publishers, Inc., Silver Spring, MD). 


\section{OUTREACH ACTIVITIES}

Communication by the Yucca Mountain Project with stakeholders, interested groups, and members of the public takes place through a variety of means: print and electronic media, including the Project's web site; newsletters; fact sheets; a toll-free information number; videos; science centers; and correspondence. The Project also promotes two-way communication with technical and non-technical audiences through a speakers bureau, tour program, exhibits at key events, and meetings.

A brief recap of 1998 activities illustrates the dimensions of the institutional program. Through the speakers bureau, the Project conducted 153 presentations to civic, educational, business, and professional groups, reaching more than 10,650 people, and answered more than 1,600 phone calls and letters, providing written responses and project literature. The Project conducted more than 250 tours of the site, briefing more than 4,600 visitors. The Project filled more than 2,200 requests for Projectrelated documents, shipping more than 20,100 documents. The web site was heavily visited--over 1.5 million hits--by individuals, as well as business, educational, and government entities around the world.

Also in 1998, the Project extended educational opportunities to almost 30,000 Nevada students in kindergarten through twelfth grade, as well as more than 300 Nevada teachers and parents, through such activities as workshops on energy, geology, and environmental studies; classroom presentations; field trips; science "discovery days"; and scout merit badge workshops.

\section{THE PUBLIC TOUR PROGRAM}

One institutional program that was assigned a high priority for communicating with the public is the Yucca Mountain Public Tour Program. This program provides a good example of communication with the public about a controversial and complex project.

The Yucca Mountain Project has always been open to public inspection, and groups that expressed an interest have toured the facility from its very beginning. In fact, over 35,000 people have toured the site since 1990. However, it was not until February 1991 that the Project opened tours to the general public by publishing an invitation in the local press. Within 10 days, more than 1,200 people had accepted the invitation. Since then, thousands of members of the public have taken advantage of the opportunity to observe work in progress at the site and talk to the scientists and engineers who are studying the geology, hydrology, weather patterns, and flora and fauna of the area. Many visitors. credit this "first-hand" experience with increasing their level of confidence in the technical personnel and the work being done.

Tours are provided throughout the year for interested groups and organizations. However, public tours take place six times a year on Saturdays during spring and fall months. On a typical tour, visitors are driven to the site some 100 miles northwest of Las Vegas via buses chartered by the Project. On each bus, there are Project representatives who serve as guides and escorts. While on the buses, visitors are welcomed and briefed on the purpose and history of the repository project. 
Once at the site, visitors tour exhibits and interact with Project scientists and engineers who are available to answer questions on a variety of topics. Visitors are then shown the Exploratory Studies Facility, an 8-kilometer (5-mile) underground laboratory, where they are briefed on various aspects of the geology of Yucca Mountain and how a repository at the site might work. A trip to the crest of the mountain provides visitors with an opportunity to see key geologic and hydrologic features of the area. On the trip back to Las Vegas, visitors are encouraged to ask follow-up questions and are requested to complete a questionnaire evaluating the tour.

\section{EVALUATING THE TOUR PROGRAM}

The Public Tour Program has evolved since 1991. As work progressed at the site, the itinerary for the tours changed to permit visitors to see and do more. In addition, the evaluations the public provided have enabled the Project to learn what visitors are most interested in or concerned about and to adjust the tours to respond to those interests and concerns. For example, in 1998, a reassessment of the Public Tour Program was initiated. A multi disciplinary task force of Project personnel was appointed to review the program. Task force members represented the Project's scientific, engineering, environmental, regulatory and institutional organizations. Their charter was to determine whether the current tour program was effective in communicating to the public the most current and significant aspects of the Project.

The task force analyzed visitor questionnaires; conducted a focus group with recent tour participants; reviewed the tour itinerary, public information materials, and exhibits; interviewed tour guides; and visited the site. Upon completion of its study, the task force recommended several changes to the tours which were subsequently implemented:

- A "welcome" video was produced to be shown on the bus during the ride to the site. The video describes to visitors what they will be seeing and doing during the day-long tour.

- A tour brochure was created to distribute to visitors. The brochure provides a simplified, current overview of the Project.

- New exhibits for the site were created and existing exhibits were updated to illustrate new features of design or recent scientific investigations.

- A standardized briefing manual was developed for use by tour guides. This ensures that all visitors receive similar information regardless of when they tour the site.

- Finally, a training course for tour guides was developed and conducted. The course covers information about the Project and the site, as well as basic communication techniques.

\section{MEASURING THE SUCCESS OF THE TOUR PROGRAM}

By observation alone, the tour program was a success. The implication was, that the Project was doing something right. Every seat on every date was filled. Visitors demonstrated an enthusiastic interest in all aspects of the Project. Following each tour, the escorts and assistants expressed a feeling of 
accomplishment and stated that the visitors seemed to take away a heightened sense of confidence in the work that was being done at the site. However, this was totally subjective and no quantitative data or statistics were available to objectively measure the public's impressions prior to taking a tour or to demonstrate a change in attitude after completing a tour. Yet, Project personnel believed that the tours were making a definite and measurable difference.

In 1994, a tour questionnaire was constructed and introduced as a component of the tour. It was distributed at the end of the site visit. The questions were simple and specific, with the intent of isolating public opinion, to the degree possible without a major investment of time and money, regarding the Yucca Mountain Project and its mission. The questionnaire identified several distributive factors of the group, such as gender, education, age, residence and manner of obtaining tour information. Specific questions asked for an evaluation or response to the individual components of the tour. Additional questions attempted to provide the Project with insight into public attitudes prior to and following a site visit. Each answer hopefully would help the Project gain an understanding of what impact the tour program had on Nevada citizens.

As years passed and evaluations were tabulated, the general results varied only by a few percentages ${ }^{2}$. In response to questions regarding the visitors' opinion on whether the Department should continue to study Yucca Mountain the change is toward the positive by a $15 \%$ to $28 \%$ margin. When guests are asked their opinion on the level of confidence they have in the ability of the Department to meet the requirements of the Nuclear Waste Policy Act, the level of confidence increases by $30 \%$ to $48 \%$. These indicators, though self-selecting and nominal in nature, do provide a basis for confidence in the ability of the tour program to change opinion.

Along with measuring the general opinions of the visitors, several components of the tour were determined to have an impact on the results. The most significant impact was the opportunity the guests had to interact with Project personnel who are doing the technical work. Closely following this component were the visits to the underground laboratory and to the top of the mountain. Both of these contributed to the increase in support for the study. The interaction with staff provided the basis for the increase in confidence in the Project's ability to accomplish its mission.

\section{THE VIRTUAL TOUR}

As successful as the tour program has been over the years, it is not possible for the Project to accommodate every interested citizen on a tour. In addition, many people find that an eight-hour tour is too much of a time commitment. The Project staff also realized that some people might be prevented from taking the tour due to physical limitations. Consequently, a recommendation for alternatives to the tour program was explored. After considering several options, the Project initiated a community partnership venture to produce a CD-Rom Virtual Tour including a 360- degree view from the top of Yucca Mountain. (Attached)

${ }^{2}$ Public Open House Tour Analysis, 1998-1999, Yucca Mountain Site Characterization Project. 
Using a series of videos, photos, text and animations, the Virtual Tour mimics an actual tour to the site. It is an interactive armchair exploration of Project activities, which provides the viewer with several layers of information that can be ignored or accessed based on their interests. A partnership between the Project and the University of Nevada-Las Vegas produced this computer-based tour using the multimedia software program, Macromedia Authorware ${ }^{\mathrm{TM}}$.

The Virtual Tour was beta tested in Nevada at the Project's three community Science Centers and on a specified set of employee computers. At the Science Centers, the staff asked viewers for feedback. A phased approach was used to accomplish the task and each phase was made available at the centers and to the identified group of staff members. Over a three-year period components were added, modified or removed based on feedback from the public and internal reviewers. All of the responses were integrated into the core product as the phases evolved.

When the last phase was completed, the Virtual Tour was presented to a Nevada-specific stakeholder group. It received an enthusiastic response. Every member of the group asked for copies of the Virtual Tour for their constituencies. Subsequently, the $C D$ was mailed to a select group of national stakeholders. At the same time, the disk was distributed internally. The reception nationally and internally was, again, very positive. The Project's expectation had been that the Virtual Tour would generate limited interest. However, this has not been the case. In every instance where the staff has demonstrated the $\mathrm{CD}$, (at exhibits, at schools, in presentations, at speaking engagements), there has been an immediate demand for copies. The Project now distributes between 50 and 75 Virtual Tours a month.

The question to be addressed now is "how effective is the Virtual Tour?" As with many good ideas that develop a life of their own, we have not yet developed the tools to measure the Virtual Tour's effectiveness. The distribution list now grows by word-of-mouth request or as an adjunct product to other outreach programs. However, if success can be measured by demand, then the Virtual Tour is a success. Together with the site tour, the Virtual Tour enables the public to gain an understanding of a controversial and complex program. 


\section{PUBLIC OPEN HOUSE TOURS}

\section{MARCH 14, APRIL 18, MAY 16, AND JUNE 13, 1998}

783 GUESTS - 615 RESPONDED

\begin{tabular}{|}
\begin{tabular}{|c|c|c|c|c|}
\hline \multicolumn{5}{|c|}{ GUESTS' OPINIONS ON STUDYING YUCCA MOUNTAIN } \\
\hline $\begin{array}{c}\text { NUMBER OF GUESTS \& \%s } \\
\text { BEFORE TOUR }\end{array}$ & \multicolumn{3}{c|}{ NUMPONSE } & 48 AFTER TOUR \\
\hline 378 & $61 \%$ & YES & 57 & $79 \%$ \\
\hline 160 & $26 \%$ & UNDECIDED & 46 & $8 \%$ \\
\hline 62 & $10 \%$ & NO & 24 & $4 \%$ \\
\hline 15 & $3 \%$ & NO ANSWER & 615 & $100 \%$ \\
\hline 615 & $100 \%$ & ****TOTALS & \\
\hline
\end{tabular}
\end{tabular}

\begin{tabular}{|c|c|c|c|c|}
\hline \multicolumn{5}{|c|}{ GUESTS' OPINIONS ON LEVELS OF CONFIDENCE } \\
\hline \multicolumn{3}{|c|}{$\begin{array}{l}\text { NUMBER OF GUESTS \& \%s } \\
\text { BEFORE TOUR }\end{array}$} & \multicolumn{2}{|c|}{$\begin{array}{c}\text { NUMBER OF GUESTS \& \%s } \\
\text { AFTER TOUR }\end{array}$} \\
\hline 106 & $17 \%$ & NOT AT ALL CONFIDENT & 27 & $4 \%$ \\
\hline 310 & $50 \%$ & SOMEWHAT CONFIDENT & 211 & $34 \%$ \\
\hline$\overline{162}$ & $26 \%$ & VERY CONFIDENT & 357 & $58 \%$ \\
\hline 37 & $7 \%$ & NO ANSWER & 20 & $4 \%$ \\
\hline 615 & $100 \%$ & 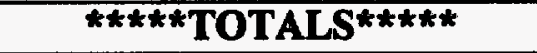 & 615 & $100 \%$ \\
\hline
\end{tabular}

SEPTEMBER 12, OCTOBER 17, AND NOVEMBER 21, 1998

717 GUESTS - 496 RESPONDED

\begin{tabular}{|c|c|c|c|c|}
\hline \multicolumn{5}{|c|}{ GUESTS' OPINIONS ON STUDYING YUCCA MOUNTAIN } \\
\hline \multicolumn{3}{|c|}{$\begin{array}{l}\text { NUMBER OF GUESTS \& \%s } \\
\text { BEFORE TOUR }\end{array}$} & \multicolumn{2}{|c|}{$\begin{array}{c}\text { NUMBER OF GUESTS \& \%s } \\
\text { AFTER TOUR }\end{array}$} \\
\hline$\overline{315}$ & $64 \%$ & YES & 397 & $80 \%$ \\
\hline 102 & $21 \%$ & UNDECIDED & 31 & $5 \%$ \\
\hline 49 & $10 \%$ & No & 27 & $5 \%$ \\
\hline 29 & $10 \%$ & NO ANSWER & 41 & $10 \%$ \\
\hline 496 & $100 \%$ & 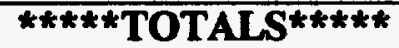 & 496 & $100 \%$ \\
\hline
\end{tabular}

\begin{tabular}{|c|c|c|c|c|}
\hline \multicolumn{5}{|c|}{ GUESTS' OPINIONS ON LEVELS OF CONFIDENCE } \\
\hline \multicolumn{3}{|c|}{$\begin{array}{l}\text { NUMBER OF GUESTS \& \%s } \\
\text { BEFORE TOUR }\end{array}$} & \multicolumn{2}{|c|}{$\begin{array}{c}\text { NUMBER OF GUESTS \& \% } \\
\text { AFTER TOUR }\end{array}$} \\
\hline 89 & $18 \%$ & NOT AT ALL CONFIDENT & 19 & $4 \%$ \\
\hline 243 & $49 \%$ & SOMEWHAT CONFIDENT & 130 & $26 \%$ \\
\hline 125 & $25 \%$ & VERY CONFIDENT & $\overline{314}$ & $63 \%$ \\
\hline 39 & $8 \%$ & NO ANSWER & 33 & $7 \%$ \\
\hline 496 & $100 \%$ & 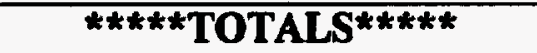 & 496 & $100 \%$ \\
\hline
\end{tabular}




\section{PUBLIC OPEN HOUSE TOURS}

\section{MARCH 13, APRIL 17, MAY 22 AND JUNE 16, 1999}

771 GUESTS - 512 RESPONDED

\begin{tabular}{|c|c|c|c|c|}
\hline \multicolumn{5}{|c|}{ GUESTS' OPINIONS ON STUDYING YUCCA MOUNTAIN } \\
\hline \multicolumn{2}{|c|}{$\begin{array}{l}\text { NUMBER OF GUESTS \& \%s } \\
\text { BEFORE TOUR }\end{array}$} & \multirow{2}{*}{$\begin{array}{c}\text { RESPONSE } \\
\text { YES }\end{array}$} & \multicolumn{2}{|c|}{$\begin{array}{c}\text { NUMBER OF GUESTS \& \%S } \\
\text { AFTER TOUR }\end{array}$} \\
\hline 277 & $54 \%$ & & 399 & $78 \%$ \\
\hline 141 & $28 \%$ & UNDECIDED & 38 & $7 \%$ \\
\hline 65 & $13 \%$ & No & 34 & $7 \%$ \\
\hline 29 & $5 \%$ & NO ANSWER & 41 & $8 \%$ \\
\hline 512 & $100 \%$ & 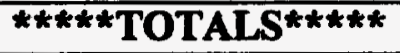 & 512 & $100 \%$ \\
\hline
\end{tabular}

\begin{tabular}{|c|c|c|c|c|}
\hline \multicolumn{5}{|c|}{ GUESTS' OPINIONS ON LEVELS OF CONFIDENCE } \\
\hline \multicolumn{3}{|c|}{$\begin{array}{l}\text { NUMBER OF GUESTS \& \%s } \\
\text { BEFORE TOUR }\end{array}$} & \multicolumn{2}{|c|}{$\begin{array}{l}\text { IBER OF GUESTS \& \%s } \\
\text { AFTER TOUR }\end{array}$} \\
\hline 94 & $18 \%$ & NOT AT ALL CONFWENT & 14 & $3 \%$ \\
\hline 269 & $53 \%$ & SOMEWHAT CONFIDENT & 151 & $29 \%$ \\
\hline 109 & $21 \%$ & VERY CONFIDENT & 325 & $64 \%$ \\
\hline 40 & $8 \%$ & NO ANSWER & 22 & $4 \%$ \\
\hline$\overline{512}$ & $100 \%$ & 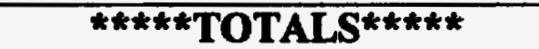 & $\mathbf{5 1 2}$ & $100 \%$ \\
\hline
\end{tabular}

\section{SEPTEMBER 11, OCTOBER 16, AND NOVEMBER 20, 1999 \\ 754 GUESTS - 573 RESPONDED}

\begin{tabular}{|c|c|c|c|c|}
\hline \multicolumn{5}{|c|}{ GUESTS' OPINIONS ON STUDYING YUCCA MOUNTAIN } \\
\hline \multicolumn{3}{|c|}{$\begin{array}{l}\text { NUMBER OF GUESTS \& \%s } \\
\text { BEFORE TOUR }\end{array}$} & \multicolumn{2}{|c|}{$\begin{array}{c}\text { NUMBER OF GUESTS \& \%s } \\
\text { AFTER TOUR }\end{array}$} \\
\hline 314 & $55 \%$ & YES & 4421 & $73 \%$ \\
\hline 161 & $28 \%$ & UNDECIDED & 61 & $11 \%$ \\
\hline 64 & $11 \%$ & NO & 46 & $8 \%$ \\
\hline 34 & $6 \%$ & NO ANSWER & 45 & $8 \%$ \\
\hline 573 & $100 \%$ & 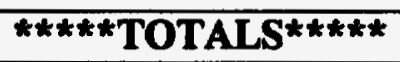 & 512 & $100 \%$ \\
\hline
\end{tabular}

\begin{tabular}{|c|c|c|c|c|c|}
\hline \multicolumn{6}{|c|}{ GUESTS' OPINIONS ON LEVELS OF CONFIDENCE } \\
\hline \multicolumn{3}{|c|}{$\begin{array}{l}\text { NUMBER OF GUESTS \& \%s } \\
\text { BEFORE TOUR }\end{array}$} & RESPONSE & \multicolumn{2}{|c|}{$\begin{array}{l}\text { AFTER TOUR } \\
\text { AFUMS }\end{array}$} \\
\hline 120 & $21 \%$ & & T ALL CONFIDENT & 32 & $6 \%$ \\
\hline 282 & $49 \%$ & & WHAT CONFIDENT & 167 & $29 \%$ \\
\hline 122 & $21 \%$ & & RY CONFIDENT & 341 & $59 \%$ \\
\hline 49 & $9 \%$ & & NO ANSWER & 33 & $6 \%$ \\
\hline 573 & $100 \%$ & & $k^{k \star}$ TOTALS ${ }^{\star \star \star \star * *}$ & 573 & $100 \%$ \\
\hline
\end{tabular}

